RASĀYAN J. Chem.

Vol. 13 | No. 4 |2200-2206| October - December | 2020 ISSN: 0974-1496 | e-ISSN: 0976-0083 | CODEN: RJCABP

RJC http://www.rasayanjournal.com http://www.rasayanjournal.co.in

\title{
L-CYSTEINE HYDROCHLORIDE AS A COMPLEXING AGENT FOR THE DETERMINATION OF COBALT(II) BY SPECTROPHOTOMETRIC METHOD
}

\author{
Ashwini, ${ }^{1 *}$, Gopalakrishna Bhat N. ${ }^{2}$ and Ronald A. Nazareth ${ }^{1}$ \\ ${ }^{1}$ Department of Chemistry, St. Aloysius College, 575003, (Karnataka), India \\ ${ }^{2}$ Department of Chemistry, Srinivas Institute of Technology, 574143, (Karnataka), India \\ *E-mail: ashwinichem27@gmail.com
}

\begin{abstract}
In this study, a sensitive and selective spectrophotometric method has been developed for the estimation of cobalt(II) by using a new chromogenic reagent. The maximum absorbance was found to be at $356 \mathrm{~nm}$. Experimental conditions were optimized. Beer's law was seen in $1.786-11.786 \mu \mathrm{g} / \mathrm{mL}$ of cobalt concentration range. Calculated molar absorptivity is $3.7535 \times 10^{3} \mathrm{~L} / \mathrm{mol} / \mathrm{cm}$. The study of interference of common ions was carried out. The current process was enforced for the estimation of cobalt in water samples, in an alloy and also in the pharmaceutical sample.
\end{abstract}

Keywords: Spectrophotometry, L-Cysteine Hydrochloride, Cobalt(II), Job's method, Mole ratio method

(C) RASĀYAN. All rights reserved

\section{INTRODUCTION}

Cobalt is found in chemically combined form in the earth's crust. The free element produced by reductive smelting is a hard, lustrous, silver-grey metal. Cobalt metal shows ferromagnetic behavior. The Curie temperature is found to be $1,115^{\circ} \mathrm{C} .{ }^{1}$ Cobalt shows weak reducing character, passivating oxide film protects it from oxidation.

Cobalt compounds have been utilized for centuries to transmit a rich blue color to glazes, ceramics and glass ${ }^{2}$. Cobalt is essential to the metabolism of all animals. Cobalt is the key constituent of cobalamin, also called vitamin $B_{12}$, the primary biological reservoir of cobalt as an ultra-trace element. ${ }^{3,4}$ Numerous reagents of high selectivity have been discovered, which includes heterocyclic azo dye ${ }^{5}$, porphyrin reagent ${ }^{6}$, fluorescent ketone reagent ${ }^{7}$, Schiff base $^{8}$ and triazene reagent. ${ }^{9}$

Several spectrophotometric determinations of cobalt in trace amount were done, for example by using 4(6-nitro-2-benzothiazolylazo) resorcinol ${ }^{10}$, bis(5-bromosalicylaldehyde) ${ }^{11}$, hydroxytriazene as selective chelating agents ${ }^{12}$ and quantitative determination of the cobalt-containing phthalocyanine fragments antitumor drugs ${ }^{13}$. The main class of chemical compounds receiving attention in scientific research are azo compounds, which exhibits high color and have been utilized as dyes and pigments for along times ${ }^{14}$, ethyl cyano (2-methyl carboxylate phenyl azo acetate) (ECA) ${ }^{15}$, 2-(5-bromo-2-pyridylazo)-5-[N-n-propyl$\mathrm{N}$-(3-sulfopropyl)amino]aniline ${ }^{16}$, [2-(4-methoxyphenyl) azo(4,5-diphenylimidazole) $]^{17}, 2,6$-Dithiolphen $\mathrm{ol}$ and its derivatives in the presence of Hydrophobic Amines. ${ }^{18}$

Most of the methods which were reported earlier include heating, extraction and the many reagents that are not selective. The reagent used in the present work is found to be selective in nature. It does not require heating and extraction. This work develops a new spectrophotometric method which is a speedy and easy method and also to provide high-quality results for cobalt determination in trace amounts in samples of water, steel and pharmaceutical samples.

\section{EXPERIMENTAL}

\section{Material and Methods}

Spectrophotometric measurements were done using Agilent Cary win UV software-based spectrophotometer, the $\mathrm{pH}$ of the different buffer solutions was measured using Systronics $\mu 361 \mathrm{pH}$ meter. High purity reagents were used. Stock solution of $0.02 \mathrm{M}$ Cobalt(II) chloride hexahydrate was

Rasayan J. Chem., 13(4), 2200-2206(2020)

http://dx.doi.org/10.31788/ RJC.2020.1345806

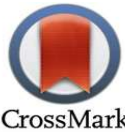


RASĀYAN J. Chem.

Vol. 13 | No. 4 |2200-2206| October - December | 2020

prepared by dissolving $1.18965 \mathrm{~g}$ in $250 \mathrm{~mL}$ standard flask using Millipore water. Reagent, L-Cysteine hydrochloride $(0.02 \mathrm{M})$ was prepared by dissolving it in a minimum quantity of Millipore water and then made up to the mark in $250 \mathrm{~mL}$ standard flask.

Different $\mathrm{pH}$ solutions from 1 to 12 were prepared using $0.2 \mathrm{M} \mathrm{KCl}$ and $0.2 \mathrm{M} \mathrm{HCl}(\mathrm{pH} 1), 0.1 \mathrm{M}$ potassium hydrogen phthalate and varying amounts of $0.1 \mathrm{M} \mathrm{HCl}(\mathrm{pH} 2-5), 0.1 \mathrm{M}$ potassium dihydrogen phosphate and varying amounts of $0.1 \mathrm{M} \mathrm{NaOH}(\mathrm{pH} 6-8), 0.025 \mathrm{M}$ borax and $0.1 \mathrm{M} \mathrm{HCl}(\mathrm{pH} 9), 0.025 \mathrm{M}$ borax and $0.1 \mathrm{M}$ $\mathrm{NaOH}(\mathrm{pH} 10), 0.05 \mathrm{M}$ disodium hydrogen phosphate and varying amounts of $0.1 \mathrm{M} \mathrm{NaOH}(\mathrm{pH} 11$ and $\mathrm{pH} 12) .{ }^{19}$

\section{General Procedure}

\section{Verification of Beer-Lambert's law}

To each set of different $10 \mathrm{~mL}$ standard flask varying volumes of $\mathrm{Co}(\mathrm{II})$ chloride solution in microliters, were added. $2 \mathrm{ml}$ of L-Cysteine hydrochloride was added in equal quantity to each standard flask which is followed by the addition of $5 \mathrm{ml}$ of buffer solution (pH11) ${ }^{20}$ and then made up to the mark by adding Millipore water. Measurement of absorbance was done at $\lambda_{\max } 356 \mathrm{~nm}$ against the blank solution. A calibration plot was drawn. ${ }^{21}$

\section{Analysis of Water Samples}

The sample of $\mathrm{Co}(\mathrm{II})$ in river water, tap water, well water, sewage water and rainwater $(10 \mu \mathrm{g} / \mathrm{ml})$ was mixed by taking a requisite amount of $\mathrm{CoCl}_{2} \cdot 6 \mathrm{H}_{2} \mathrm{O}$. Dissolving it in all types of water and transferred to a standard flask and diluted and absorbance of each sample was measured to find out the amount of $\mathrm{Co}$ (II) present. 22,23

\section{Determination of Co(II) in a Pharmaceutical Sample}

About $1 \mathrm{~mL}$ Neurobion ampoule injection sample was added to $50 \mathrm{~mL}$ standard flask, to this flask nitric acid and sulphuric acid were added in the ratio 10:1. The solution was warmed to dryness ${ }^{11,24}$. The residue was treated with dilute $\mathrm{H}_{2} \mathrm{SO}_{4}$ and the residue is diluted, till it becomes colorless. The solution was neutralized by adding sodium hydroxide. Then this solution is transferred to a standard flask and this known amount of L-cysteine and buffer solution of $\mathrm{pH} 11$ was added. Then Spectrophotometric analysis was carried out.

\section{Determination of Co(II) in An Alloy Sample}

About 0.1 to $0.5 \mathrm{~g}$ of an alloy sample, JSS $607-6$, was added to aquaregia $(15 \mathrm{~mL}$ of concentrated hydrochloric acid and $5.0 \mathrm{~mL}$ of con. $\mathrm{HNO}_{3}$ ) in a beaker. The solution was concentrated to three fourth of its volume. The addition of $10 \mathrm{~mL}$ of concentrated hydrochloric acid to the solution was followed by filtration and dilution ${ }^{25,26,27}$. Then this solution is mixed with a known quantity of L-cysteine and buffer solution of $\mathrm{pH} 11$, so that the Co(II) of an alloy sample forms the complex with L-cysteine and further analysis can be done by using a spectrophotometer.

\section{RESULTS AND DISCUSSION}

\section{Absorption Spectra of L-Cysteine and Co(II)-L-cysteine Complex}

Absorption spectra of blank and Co(II)-L-Cysteine complex were measured using a uv-visible spectrophotometer. At 356nm, the reagent blank solution did not show maximum absorbance (Fig.-1). But the maximum absorbance of the complex was found at $356 \mathrm{~nm}$ (Fig.-2). Therefore at this $\lambda_{\max }$ $(356 \mathrm{~nm})$, a detailed study of the complex was done.

\section{Impact of pH on the Complex Absorbance}

Measurement of complex absorbance at $356 \mathrm{~nm}$ using different $\mathrm{pH}$ solutions showed that maximum color intensity was produced by the use of pH11 solution (Fig.-3). Therefore the further analytical study of the complex was done by maintaining the solution $\mathrm{pH} 11$.

\section{Impact of Reagent Concentration}

The amount of reagent required for the complete formation of the complex was studied by taking $2 \mathrm{~mL}$ of $0.001 \mathrm{M} \mathrm{Co}$ (II) and adding varying volumes of L-cysteine hydrochloride solution. It was found that the absorbance of the complex was almost constant from $6.5 \mathrm{~mL}$ to $10 \mathrm{~mL}$ (Fig.-4). 
RASĀYAN J. Chem.

Vol. 13 | No. 4 |2200-2206| October - December | 2020
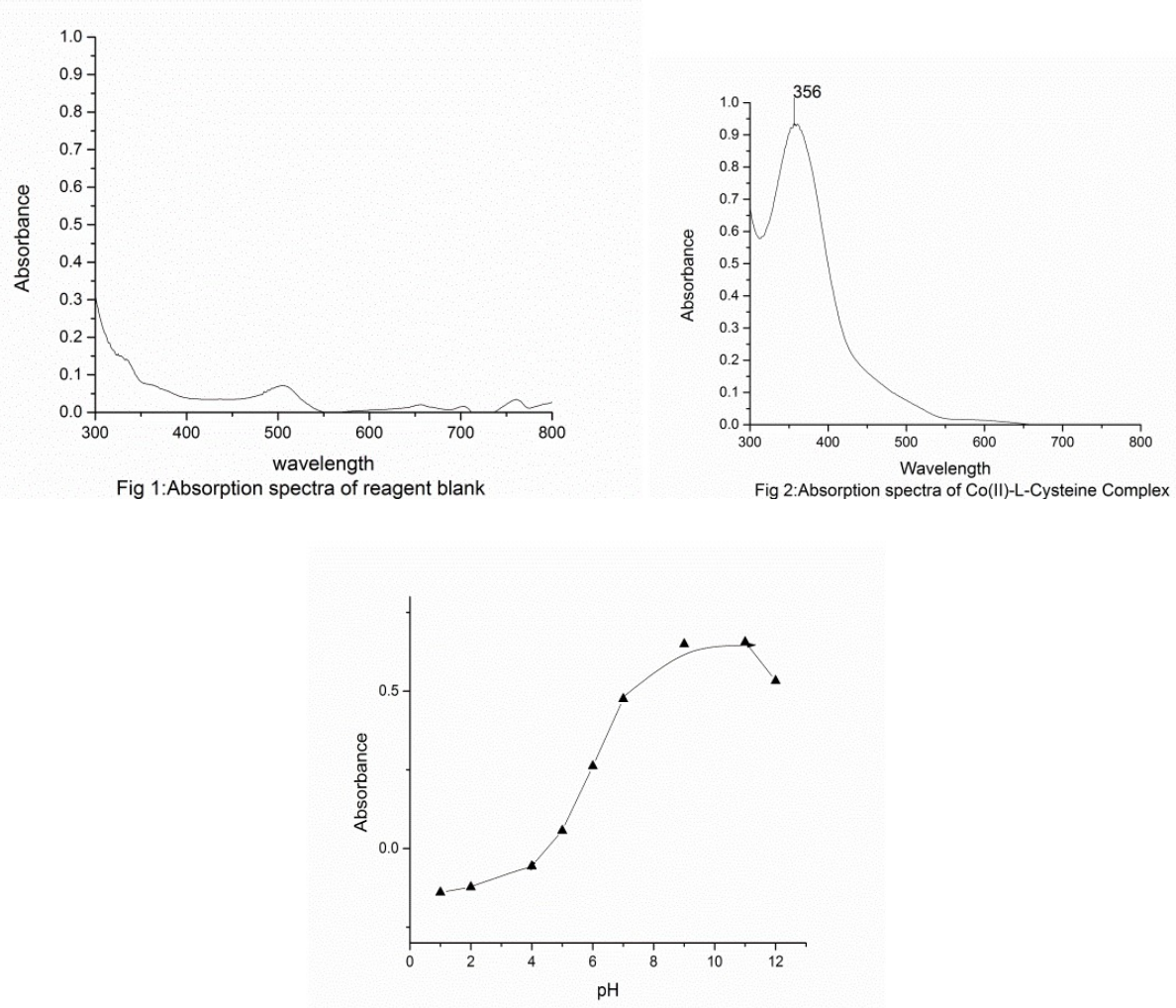

Fig.-3:Impact of $\mathrm{pH}$ on Absorbance

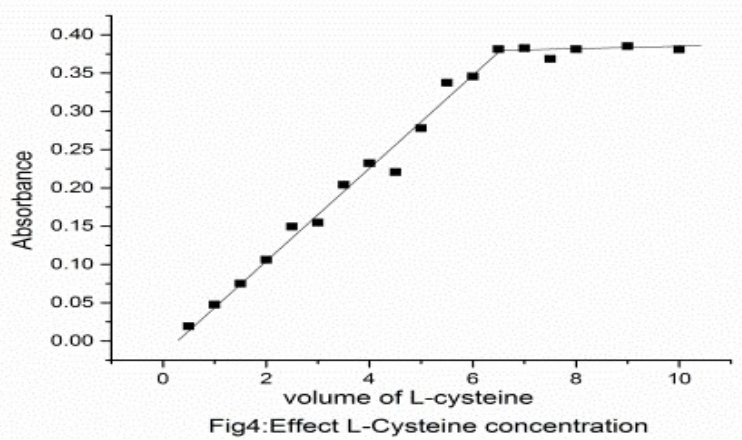

Beer's Law Sensitivity and Calibration Graph

Estimation of Co (II) at the micro-level was done by taking a different amount of Co(II) and measuring the absorbance at $356 \mathrm{~nm}$ under the optimum condition. And then the calibration plot was constructed (Fig.-5), which shows that from $1.1786 \mu \mathrm{g} / \mathrm{mL}-11.786 \mu \mathrm{g} / \mathrm{mL}$ of $\mathrm{Co}$ (II) can be estimated accurately.

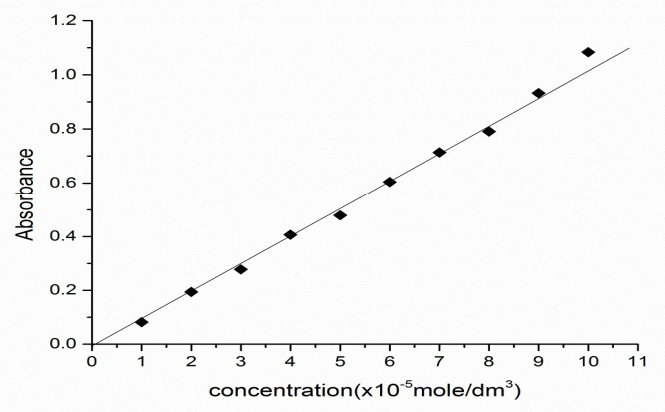

Fig.-5: Beer's Law Plot for Cobalt(II)-L-cysteine Complex 
RASĀYAN J. Chem.

Vol. 13 | No. 4 |2200-2206| October - December | 2020

\section{Stoichiometry and Nature of Complex}

The composition of the complex was found to be, 1:3 (M:L), which was determined by Job's continuous variation method (Fig.-6) and the result is supported by the mole ratio method (Fig.-7). The stability constant of the complex was found to be $1.8 \times 10^{4}$ (Fig.-8) which was determined by the turner Anderson method.

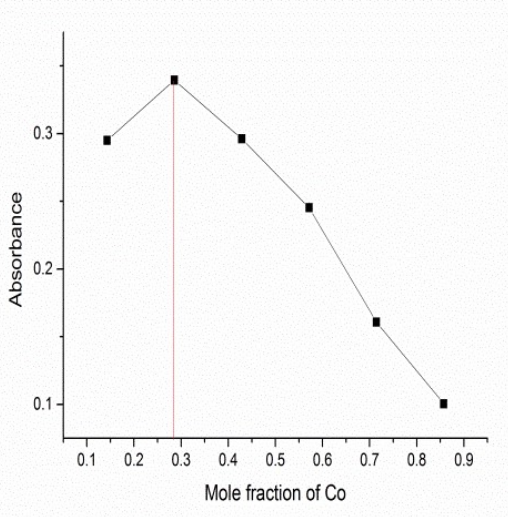

Fig 6:Job's method of continuous variation

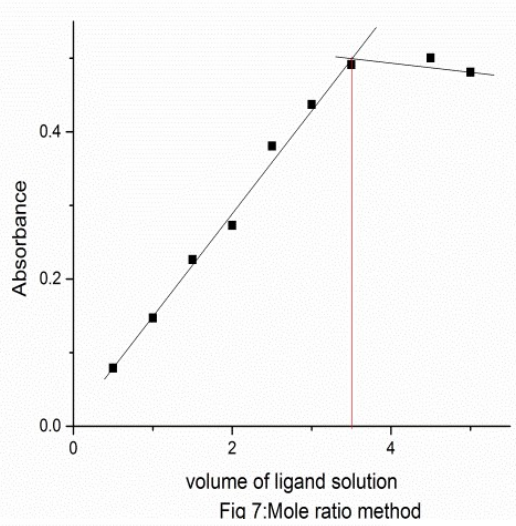

$A=[M]=[L]=1 \times 10^{-3} \mathrm{M}$

$B=[M]=[L]=0.5 \times 10^{-3} \mathrm{M}$

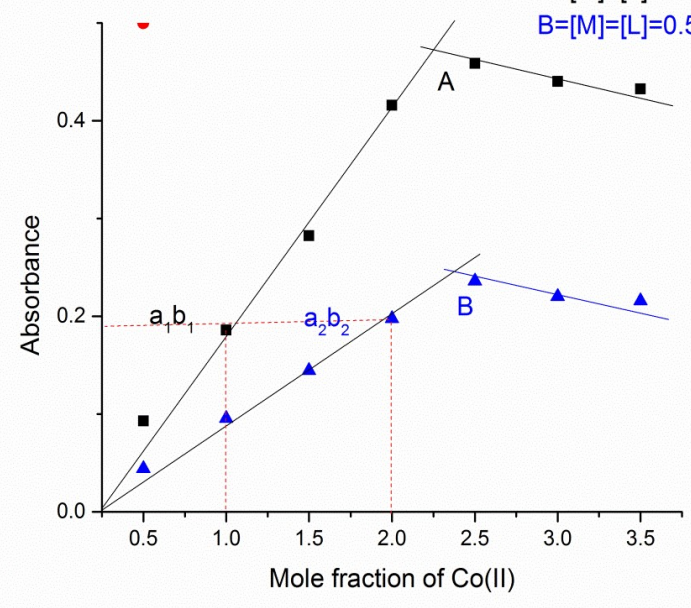

Fig.-8: Stability Constant by Turner Anderson Method

\section{Effect of Diverse Ions}

In the existence of diverse ions, the absorbance value of the complex Co(II)-L-Cysteine containing $40 \mu \mathrm{g}$ of Co(II) was examined. The outcomes of the study are displayed in Table-1.

Table-1: Study of Interference of Diverse Ions

\begin{tabular}{c|c}
\hline Ions added & Tolerance limit \\
\hline $\mathrm{Ag}(\mathrm{I})$ & 60 \\
\hline $\mathrm{Cd}(\mathrm{II})$ & 100 \\
\hline $\mathrm{Cu}(\mathrm{II})^{*}$ & 20 \\
\hline $\mathrm{Cr}(\mathrm{VI})$ & 38 \\
\hline $\mathrm{Ni}(\mathrm{II})$ & 60 \\
\hline $\mathrm{Pb}(\mathrm{II})$ & 180 \\
\hline $\mathrm{Zn}(\mathrm{II})$ & 100 \\
\hline $\mathrm{V}(\mathrm{IV})$ & 80 \\
\hline $\mathrm{Zr}(\mathrm{IV})$ & 40 \\
\hline $\mathrm{W}(\mathrm{VI})$ & 80 \\
\hline Tartrate & 400 \\
\hline \multicolumn{2}{|}{}
\end{tabular}


RASĀYAN J. Chem.

Vol. 13 | No. 4 |2200-2206| October - December | 2020

\begin{tabular}{c|c}
\hline Oxalate & 130 \\
\hline Citrate & 130 \\
\hline Nitrate & 160 \\
\hline Chloride & 140 \\
\hline Phosphate & 170 \\
\hline Sulphate & 200
\end{tabular}

*Interference of $\mathrm{Cu}$ (II) was observed, which can be nullified by the use of suitable masking agent-Thiosulphate.

The above data indicates that many associated anions and cations when they are existing in large quantities do not interfere during the estimation of $\mathrm{Co}(\mathrm{II})$.

\section{Precision and Accuracy}

To evaluate the precision and accuracy of the method, the amount of $\mathrm{Co}(\mathrm{II})$ was determined in five different samples under the reliable experimental conditions. The outcome of the study is mentioned in Table-2. The relative error and relative standard deviation are not exceeding $\pm 0.42 \%$ and $\pm 0.3 \%$. Therefore the method is found to be more precise and accurate. Table-3 provides the entire analytical data.

Table-2: Determination of Co(II) in Cobaltous Chloride Solution

\begin{tabular}{c|c|c|c|c}
\hline \multicolumn{2}{c|}{$\operatorname{Co}(\mathrm{II})(\mu \mathrm{g} / \mathrm{mL})$} & Standard Deviation & $\begin{array}{c}\text { Relative Standard } \\
\text { Deviation }\end{array}$ & Relative Error \\
\hline Taken & Found* & & 0.301 & 0.42 \\
\hline 2.36 & 2.35 & 0.007 & 0.282 & -0.28 \\
\hline 3.54 & 3.53 & 0.01 & 0.190 & 0.13 \\
\hline 4.71 & 4.70 & 0.009 & 0.142 & 0.20 \\
\hline 5.89 & 5.88 & 0.008 & 0.162 & 0.23 \\
\hline 7.07 & 7.05 & 0.01 & & \\
\hline
\end{tabular}

*Average of five determinations.

Table-3: Physico-Chemical Properties of Co(II)-L-Cysteine Complex

\section{Applications}

\begin{tabular}{c|c}
\hline Characteristics & Results \\
\hline$\lambda_{\max }$ & 356 \\
\hline Optimum pH range & 11 \\
\hline Beer's law validity range & $1.1786 \mu \mathrm{g} / \mathrm{mL}-11.786 \mu \mathrm{g} / \mathrm{mL}$ \\
\hline $\begin{array}{c}\text { Composition of the complex } \\
\text { tandard deviation in the determination of Co(II) } \\
\text { from2.36-7.07 } \mu \mathrm{g} / \mathrm{mL}\end{array}$ & 0.0088 \\
\hline Relative standard deviation & 0.215 \\
\hline Molar absorptivity & $3.7535 \times 10^{3} \mathrm{~L} / \mathrm{mol}^{-} \mathrm{cm}$ \\
\hline Sandell's sensitivity & $0.015 \mu \mathrm{gcm}{ }^{-2}$ \\
\hline
\end{tabular}

\section{Analysis of Water}

The technique was effectively applied for the estimation of Co(II) in tap water, well water, sewage water and rainwater. The results are shown in Table- 4 .

Table-4: Analysis Co(II) in Various Samples of Water

\begin{tabular}{c|c|c|c}
\hline $\begin{array}{c}\text { Various Water } \\
\text { Samples Containing } \\
\text { Co(II) }\end{array}$ & $\begin{array}{c}\text { Taken } \\
(\mu \mathrm{g})\end{array}$ & $\begin{array}{c}\text { Found } \\
(\mu \mathrm{g})\end{array}$ & Relative Error \\
\hline Tap water & 10 & 10.05 & -0.5 \\
\hline Well water & 10 & 10.12 & -1.2 \\
\hline Sewage water & 10 & 10.09 & -0.9 \\
\hline Rainwater & 10 & 10.07 & -0.7 \\
\hline
\end{tabular}

\section{Analysis of An Alloy Sample}

The current method was also applied for the estimation of $\mathrm{Co}$ (II) in an alloy sample. The result is presented in Table-5. 
RASĀYAN J. Chem.

Vol. 13 | No. 4 |2200-2206| October - December | 2020

Table-5: Estimation of Co(II) in An Alloy Sample

\begin{tabular}{c|c|c|c|c|c}
\hline Alloy & $\begin{array}{c}\text { Quantity of } \\
\text { Co(II) ion } \\
\text { present }(\mu \mathrm{g})\end{array}$ & $\begin{array}{c}\text { Amount of } \\
\text { Co(II) } \\
\text { found }(\mu \mathrm{g})\end{array}$ & $\%$ RSD & $\begin{array}{c}\text { \% Relative } \\
\text { error }\end{array}$ & $\%$ Recovery \\
\hline JSS 607-6 & 14.01 & 13.97 & 0.39 & 0.139 & 99.7 \\
\hline
\end{tabular}

\section{Analysis of the Pharmaceutical Sample}

The current method also holds good for the estimation of $\mathrm{Co}$ (II) in a Pharmaceurticle sample. The result is shown in Table-6.

Table 6: Determination of Co(II) in a Pharmaceutical Sample

\begin{tabular}{c|c|c|c|c|c|c}
\hline Sample & $\begin{array}{c}\text { Amount of } \\
\text { Co(II) ion } \\
\text { present }(\mu \mathrm{g} / \mathrm{mL})\end{array}$ & $\begin{array}{c}\text { Amount of } \\
\text { Co(II) found } \\
(\mu \mathrm{g} / \mathrm{mL})\end{array}$ & $\begin{array}{c}\% \\
\text { RSD }\end{array}$ & $\begin{array}{c}\text { AAS process } \\
(\mu \mathrm{g} / \mathrm{mL})\end{array}$ & $\begin{array}{c}\% \\
\text { RSD }\end{array}$ & $\begin{array}{c}\% \\
\text { Recovery }\end{array}$ \\
\hline Neurobion & 21.74 & 21.68 & 0.4 & 21.69 & 0.4 & 98.0 \\
\hline
\end{tabular}

\section{CONCLUSION}

The proposed method is found to be simple, speedy and accurate. It does not require heating and extraction. And also the reagent is readily available. This method can be used for the determination of the minute quantity of $\mathrm{Co}(\mathrm{II})$ in sewage water and also other water samples. And this method also can be employed in an alloy and pharmaceutical sample.

\section{ACKNOWLEDGEMENT}

The authors are grateful to the St. Aloysius College(autonomous) and Srinivas Institute of Technology for providing the chemicals and instruments.

\section{REFERENCES}

1. Enghag, Encyclopedia of the Elements: Technical Data, History, Processing, Applications, 667(2004).

2. https://en.wikipedia.org/wiki/Cobalt

3. Astrid Sigel, Helmut Sigel and K.O.Roland, Metal Ions in Life Sciences- 11, Springer, 295(2013)

4. Cracan, Valentin, Banerjee and Ruma, Metal Ions in Life Sciences- 12, Springer, 334(2013) DOI: 10.1007/978-94-007-5561-10_10

5. S. C. Macelo, C. S. F. Izabel and C. M. N. Katia, Talanta, 43,(1996), DOI:10.1016/00399140(96)01931-5

6. Sun Xi and Zhou Shi-nong, Chinese Journal of Analytical Chemistry, 18(5), (1990) DOI: $10.1109 /$ icbbe.2011.5780777

7. Xia Dao-pei and Wu Yao-hui, Chemical Reagents, 10(1), 45(1988)

8. G.R. Pandhare, V.M. Shinde and Y. H. Deshpande, Rasayan Journal of Chemistry, 1(2), 337(2008)

9. Yang Ming-hua, Gong Chu-ru, Jin Chuan-mingand She Zhi-gang, Journal of Analytical Science, 15(5), 415(1999)

10. N. A. Nassir, Iraqi-National Journal of Chemistry, 26, 263(2007)

11. M. Jamaluddin Ahmed, K. Jakir Hossan, Journal of the Iranian Chemical Society, 5, 4(2008), DOI: 10.1007/BF03246149

12. O. Ombaka and J. M. Gichumbi, African Journal of Pure and Applied Chemistry, 5(15), (2011), DOI: $10.5897 / \mathrm{AJPAC} 11.069$

13. M. S. Goizman, G. B. Tikhomrova, V. N. Kalidchenko and E. M. Kochenova, Pharmaceutical Chemistry Journal, 39(10), (2005).

14. X. Jinghai, X. Jinqiu, and Z. Defeng, Chinese Journal of Chemical Engineering, 11(1), (2003).

15. Elham Nghaimesh Mezaal, Kawther Ahmad Sadiq, Maha Abd Al-SattarMohammed, Rasmia Mahmood Rumez, International Journal of Applied Chemistry, 12(4), 699(2016).

16. Arfidyaninggar Septia Rinda, Kanchana Uraisin, Akhmad Sabarudin,Duangjai Nacapricha and Prapin Wilairat, American Journal of Chemistry, 6(4), 95(2017), DOI:10.1088/1757-899X/299/1/012006

17. Alaa F. Husseina, Raghad Saad Hatamb, Ihsan Mahdi Shaheed, International Journal of Pharmacy and Pharmaceutical Research, 6(4), 671(2016). 
RASĀYAN J. Chem.

Vol. 13 | No. 4 |2200-2206| October - December | 2020

18. Kerim A. Kuliyev, Nailya A. Verdizadeh and Geysar S. Suleymanova, American Journal of Chemistry, 6(4), 95(2016), DOI:10.5923/j.chemistry.20160604.02

19. http://delloyed.50megs.com/moreinfo/buffers2.html

20. K. G. Chandrashekhara, Gopalakrishna Bhat. N and Nagaraj, International Journal of Chemical Studies, 2(6), (2015), DOI:10.22271/chemi

21. Gul Afshan Soomroa and Ghulam Abbas Shar, International Journal of Chemical Sciences, 12(3), 982(2014)

22. Anthoney Swamy Thangiah, Rasayan Journal of Chemistry, 12(3), 1503(2019), DOI: 10.31788/RJC.2019.1235201

23. A. Mallah, S. Q. Memon, N. Memon, K. Abbasi and M. Y. Khuhawar, The Scientific World Journal, 743704, (2012), DOI:10.1100/2012/743407

24. Santosh K. Sar, Chanda Verma and Piyush K. Pandey, Rasayan Journal of Chemistry, 1(2), 236 (2008).

25. V. S. Anusuya Devi and V. Krishna Reddy, International Journal of Analytical Chemistry, 2012(2), (2012), DOI:10.1155/2012/981758

26. Karamat Mahmood, Feroza Hamid Wattoo, Muhammad Hamid Sarwar Wattoo Muhammad Imran Muhammad Javaid Asad Syed Ahmed Tirmizi, Abdul Wadood, Saudi Journal of Biological Sciences, 19(2), (2012), DOI:10.1016/j.sjbs.2012.01.001

27. Maryam Abbasi Tarighat, Abbas Afkhami, Journal of the Brazilian Chemical Society, 23(7), (2012), DOI: $10.1590 / \mathrm{S} 0103-50532012000700016$

[RJC-5806/2020] 